\title{
Three New Triterpenes from the Resinous Bark of Protium kleinii and their Antinociceptive Activity
}

\author{
Fabiana V. Lima ${ }^{a}$, Angela Malheiros ${ }^{*, b}$, Michel F. Otuki ${ }^{c}$, João B. Calixto ${ }^{c}$, Rosendo A. Yunes ${ }^{a}$, \\ Valdir Cechinel Filho ${ }^{b}$ and Franco Delle Monache ${ }^{d}$ \\ ${ }^{a}$ Departamento de Quimica, Universidade Federal de Santa Catarina, 88040-900 Florianópolis -SC, Brazil \\ ${ }^{b}$ Núcleo de Investigações Químico-Farmacêuticas, Universidade do Vale do Itajaí, CP 360, \\ 88302-202 Itajaí - SC, Brazil \\ ${ }^{c}$ Departamento de Farmacologia, Universidade Federal de Santa Catarina, 88015-420 Florianópolis - SC, Brazil \\ ${ }^{d}$ Istituto di Biochimica e Biochimica Clinica, Università Cattolica, Roma, Italy
}

\begin{abstract}
Três triterpenos pentacíclicos inéditos foram isolados da resina de Protium kleinii. Suas estruturas, 3-oxo-11 $\beta, 16 \beta$-diidróxi-urs-12-eno (1), 3-oxo-11 $\beta$-hidróxi-urs-12-eno (2) e 3-oxo-11 $\beta$-hidróxiolean-12-eno (3), foram elucidadas por espectroscopia de RMN. A administração sistêmica destes compostos (10-100 mg kg-1, i.p.) foi capaz de inibir tanto a primeira quanto a segunda fase da nocicepção induzida pela formalina em camundongos. Em adição, foram isolados os triterpenos conhecidos $3 \beta, 16 \beta$-dihidróxi-urs-12-eno (breina) (4) e uma mistura de $\alpha$ (5)- e $\beta$-amirina (6).

Three novel pentacyclic triterpenes have been isolated from the resin of Protium kleinii and their structures elucidated by NMR spectroscopy as 3-oxo-11 $\beta, 16 \beta$-dihydroxy-urs-12-ene (1), 3-oxo$11 \beta$-hydroxy-urs-12-ene (2) and 3-oxo-11 $\beta$-hydroxy-olean-12-ene (3). The systemic administration of the above compounds (10-100 mg kg-1, i.p.) was able to inhibited both first and second phase of the formalin-induced nociception in mice. The known triterpenes $3 \beta, 16 \beta$-dihydroxy-olean-12-ene (brein) (4) and a mixture of $\alpha(5)$ - and $\beta$-amyrin (6) were also found.
\end{abstract}

Keywords: Protium kleinii, Burseraceae, pentacyclic triterpenes, antinociceptive activity

\section{Introduction}

Plants of the genus Protium (Burseraceae) are known for the production of a resin exudate used for skin diseases, healings of ulcers, scirrhous and as an analgesic. ${ }^{1}$ Essential oils from the leaves and resin of various Protium spp. have been evaluated for their anti-inflammatory activity. 2,3 Triterpenes, mainly of the oleane and ursane series, occur as binary mixtures in the resin. ${ }^{4,5}$ Protium kleinii Cuatrecas is endemic in southern Brazil, where it is known as "almecega", "almiscar", "pau-de-breu" and "guapoi", inter alia. $^{6}$

In an earlier paper ${ }^{7}$ we reported the antinociceptive activity of the ether soluble portion and of $3 \beta, 16 \beta$ dihydroxy-urs-12-ene (brein) obtained from its resin.

In the present paper, we report the full phytochemical study of the resinous bark and the structural determination

*e-mail: angela@ccs.univali.br of three novel pentacyclic triterpenes, 3-oxo-11 $\beta, 16 \beta$ dihydroxy-urs-12-ene (1), 3-oxo-11 $\beta$-hydroxy-urs-12-ene (2), and 3-oxo-11 $\beta$-hydroxy-olean-12-ene (3), the last two isolated and analyzed as a mixture. The known triterpenes $3 \beta, 16 \beta$-dihydroxy-olean-12-ene (brein) (4) and a mixture of $\alpha(5)$ - and $\beta$-amyrin (6) were also found. Futhermore the present study was aimed at evaluating the possible antinociceptive action of this pentacyclic triterpenes in a chemical model of nociception in mice.

\section{Results and Discussion}

Conventional chromatographic separation of the ethyl ether soluble portion of the resinous bark led to the isolation of a mixture of $\alpha(5)$ - and $\beta$-amyrin (6) and of $3 \beta, 16 \beta$-dihydroxy-urs-12-en (brein) (4) as the main components. Compound $\mathbf{1}$ and an unseparable mixture of $\mathbf{2}$ and $\mathbf{3}$ were also obtained by extended purification and repeated crystallizations. 


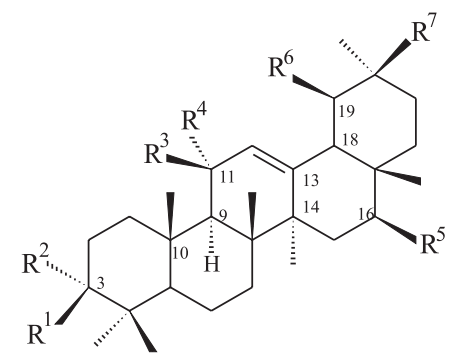

1: $\mathrm{R}^{1}=\mathrm{R}^{2}=\mathrm{O} ; \mathrm{R}^{3}=\mathrm{R}^{5}=\mathrm{OH} ; \mathrm{R}^{4}=\mathrm{R}^{7}=\mathrm{H} ; \mathrm{R}^{6}=\mathrm{CH}_{3}$

2: $R^{1}=R^{2}=\mathrm{O} ; R^{3}=\mathrm{OH} ; R^{4}=R^{5}=R^{7}=H ; R^{6}=\mathrm{CH}_{3}$

3: $\mathrm{R}^{1}=\mathrm{R}^{2}=\mathrm{O} ; \mathrm{R}^{3}=\mathrm{OH} ; \mathrm{R}^{4}=\mathrm{R}^{5}=\mathrm{R}^{6}=\mathrm{H} ; \mathrm{R}^{7}=\mathrm{CH}_{3}$

4: $\mathrm{R}^{1}=\mathrm{R}^{5}=\mathrm{OH} ; \mathrm{R}^{2}=\mathrm{R}^{3}=\mathrm{R}^{4}=\mathrm{R}^{7}=\mathrm{H} ; \mathrm{R}^{6}=\mathrm{CH}_{3}$

5: $\mathrm{R}^{1}=\mathrm{OH} ; \mathrm{R}^{2}=\mathrm{R}^{3}=\mathrm{R}^{4}=\mathrm{R}^{7}=\mathrm{H} ; \mathrm{R}^{6}=\mathrm{CH}_{3}$

6: $R^{1}=\mathrm{OH} ; \mathrm{R}^{2}=\mathrm{R}^{3}=\mathrm{R}^{4}=\mathrm{R}^{6}=\mathrm{H} ; \mathrm{R}^{7}=\mathrm{CH}_{3}$

7: $\mathrm{R}^{1}=\mathrm{R}^{2}=\mathrm{O} ; \mathrm{R}^{4}=\mathrm{OH} ; \mathrm{R}^{3}=\mathrm{R}^{5}=\mathrm{R}^{7}=\mathrm{H} ; \mathrm{R}^{6}=\mathrm{CH}_{3}$

8: $R^{1}=R^{2}=\mathrm{O} ; R^{4}=\mathrm{OH} ; R^{3}=R^{5}=R^{6}=H ; R^{7}=\mathrm{CH}_{3}$

The molecular formula $\mathrm{C}_{30} \mathrm{H}_{48} \mathrm{O}_{3}$ was assigned to compound 1 for the molecular peak at $m / z, 456$ in the EIMS, for the presence of thirty signals in the ${ }^{13} \mathrm{C}$ NMR spectrum and for elemental analysis. The ${ }^{1} \mathrm{H}$ NMR spectrum showed signals attributable to eight methyls, two of which in secondary carbon $(\delta 0.95, \mathrm{~d}, J 7.0 \mathrm{~Hz} ; \delta 0.89, \mathrm{~d}, J 6.3 \mathrm{~Hz})$, to an olefinic proton $(\delta 5.44, \mathrm{~d}, J 2.7 \mathrm{~Hz})$ and to two hydroxymethines $(\delta 4.25$, dd, $J 11.1$ and $5.2 \mathrm{~Hz} ; \delta 4.59$, dd, $J 9.8$ and $2.7 \mathrm{~Hz}$ ). In the ${ }^{13} \mathrm{C} \mathrm{NMR}$ spectrum, inter alia, signals for a saturated carbonyl ( $\delta 217.9)$, two oximethines $(\delta 81.7$ and 66.7) and a trisubstituted double bond $(\delta 125.4$ and 144.2) were evident. The unequivocal assignements of each NMR signal are reported in Table 1 as a result of 1D- and 2D-NMR experiments. Cumulatively, these data suggested an urs-12-ene triterpenoid with a carbonyl and two hydroxy substituents. Comparison of ring A signal with those of methyl-3-oxo-ursolate ${ }^{8}$ permitted the location of the carbonyl on position 3 .

Analogously, one of the hydroxy groups $\left(\delta_{\mathrm{C}} 66.7 ; \delta_{\mathrm{H}}\right.$ 4.25) was put on position 16 by comparison with the data of brein, $4 \mathrm{CH}-16\left(\delta_{\mathrm{C}} 67.0 ; \delta_{\mathrm{H}} 4.22\right.$, dd, $J 11.3$ and $\left.5.3 \mathrm{~Hz}\right)$, including the signals of the carbons 14-18, 22 and 28 to 30 (Table 1).

Finally, decoupling experiments established the position 11 for the second hydroxymethine $\left(\delta_{\mathrm{C}} 81.7 ; \delta_{\mathrm{H}}\right.$ 4.59 , dd, $J 9.8$ and $2.7 \mathrm{~Hz}$ ). In fact, the irradiation at $\delta 4.59$ (H-11) changes to singlets both signals at $\delta 5.44(\mathrm{H}-12)$ and at $\delta 1.98(\mathrm{H}-9)$. Conversely, by irradiating at $\delta 5.44$ or at $\delta 1.98$ the signal of $\mathrm{H}-11$ becomes a doublet $(J 2.7 \mathrm{~Hz}$ or $J 9.8 \mathrm{~Hz}$, respectively). Therefore, compound $\mathbf{1}$ is 3-oxo$11 \beta, 16 \beta$-dihydroxyurs-12-ene with the stereochemistry in 11 to be established.

Compounds $\mathbf{2}$ and $\mathbf{3}$ were obtained as a 2:3 mixture after repeated attempts of chromatographic purification
Table 1. NMR spectral data for $\mathbf{1}$ and $\mathbf{4}$

\begin{tabular}{|c|c|c|c|}
\hline \multicolumn{3}{|c|}{1} & \multirow{2}{*}{$\begin{array}{c}\mathbf{4} \\
\delta_{\mathrm{C}} \\
\end{array}$} \\
\hline $\mathrm{H} / \mathrm{C}$ & $\delta_{\mathrm{C}}$ & $\delta_{\mathrm{H}}$ & \\
\hline 1 & 40.3 & $2.40 ; 1.70$ & 38.8 \\
\hline 2 & 34.2 & 2.43 & 27.2 \\
\hline 3 & 217.9 & & 79.0 \\
\hline 4 & 47.6 & & 38.8 \\
\hline 5 & 55.2 & 1.40 & 55.2 \\
\hline 6 & 19.6 & 1.50 & 18.3 \\
\hline 7 & 33.0 & 1.80 & 32.9 \\
\hline 8 & 43.2 & & 40.1 \\
\hline 9 & 47.2 & $1.98 \mathrm{~d}(9.8)$ & 47.0 \\
\hline 10 & 37.3 & & 36.8 \\
\hline 11 & 81.7 & $4.59 \mathrm{dd}(9.8 ; 2.7)$ & 23.4 \\
\hline 12 & 125.4 & $5.44 \mathrm{~d}(2.7)$ & 125.1 \\
\hline 13 & 144.2 & & 138.0 \\
\hline 14 & 44.2 & & 44.0 \\
\hline 15 & 35.8 & $1.68 ; 1.42$ & 36.0 \\
\hline 16 & 66.7 & $4.25 \mathrm{dd}(11.1 ; 5.2)$ & 67.0 \\
\hline 17 & 38.5 & & 38.5 \\
\hline 18 & 60.3 & 1.67 & 60.7 \\
\hline 19 & 39.4 & 1.32 & 39.6 \\
\hline 20 & 39.2 & 1.32 & 39.5 \\
\hline 21 & 30.4 & 1.80 & 30.5 \\
\hline 22 & 35.0 & 2.03 & 35.2 \\
\hline 23 & 26.0 & $1.12 \mathrm{~s}$ & 28.1 \\
\hline 24 & 21.4 & $1.08 \mathrm{~s}$ & 15.6 \\
\hline 25 & 18.0 & $1.15 \mathrm{~s}$ & 15.7 \\
\hline 26 & 16.2 & $1.17 \mathrm{~s}$ & 16.8 \\
\hline 27 & 23.2 & $1.25 \mathrm{~s}$ & 24.5 \\
\hline 28 & 21.9 & $0.79 \mathrm{~s}$ & 21.9 \\
\hline 29 & 17.7 & $0.95 \mathrm{~d}(7.0)$ & 17.6 \\
\hline 30 & 21.2 & $0.89 \mathrm{~d}(6.3)$ & 21.6 \\
\hline
\end{tabular}

Coupling constants (in $\mathrm{Hz}$ ) in parentheses.

and crystallization. The mixture showed a molecular peak in the mass spectrum at $m / z, 440$ and analyzed for $\mathrm{C}_{30} \mathrm{H}_{48} \mathrm{O}_{2}$, but exhibited two sets of signals both in the ${ }^{1} \mathrm{H}$ and ${ }^{13} \mathrm{C}$ NMR spectra. In the proton spectrum were evident two doublets at $\delta 5.38$ and $5.45(J 2.8 \mathrm{~Hz})$ (ratio 2:3) and two double doublet at $\delta 4.56$ and $4.59(J 9.4$ and $2.8 \mathrm{~Hz})$, which highly resemble the signals $\mathrm{H}-12$ and $\mathrm{H}-11$, respectively, of compound $\mathbf{1}$. The carbon spectrum disclosed fifty-six signals with a pair of signals at $\delta 124.8 / 121.2$, at $\delta 146.1 /$ 152.8 , at $\delta 218.0 / 217.8$ and at $\delta 81.8 / 82.0$. Therefore the mixture was considered to be constituted by two triterpenes of the ursane/oleane series with a carbonyl and an hydroxyl. Careful examination of the multiplicity of the signals in the DEPT experiment permitted the carbon assignments of $\mathbf{2}$ and of $\mathbf{3}$ as reported in Table 2; for instance, C-18 and $\mathrm{C}-19$ are $\mathrm{CH}$ in the ursane 2, while they are $\mathrm{CH}$ and $\mathrm{CH}_{2}$, respectively, in the oleane $\mathbf{3}$. According to the method developed by Maia et al. ${ }^{4}$ and Olea and Roque, ${ }^{9}$ the assignments were corroborated by comparison with the data of ursane/oleane pairs in the literature, ${ }^{10}$ by the relative intensity of the signals and by the Hetcor spectrum. In addition, in the Inept experiment the irradiation at $\delta$ 4.56- 
Table 2. ${ }^{13} \mathrm{C}$ NMR data for compounds $\mathbf{2 , 3}$ and $\mathbf{7 , 8}$

\begin{tabular}{|c|c|c|c|c|}
\hline C & 2 & $7^{11}$ & 3 & $8^{12}$ \\
\hline 1 & 40.1 & 41.4 & 40.3 & 41.1 \\
\hline 2 & 34.2 & 34.3 & 34.2 & 32.8 \\
\hline 3 & 218.0 & 217.6 & 217.8 & 217.4 \\
\hline 4 & 47.6 & 47.7 & 47.7 & 47.7 \\
\hline 5 & 55.3 & 55.6 & 55.3 & 54.9 \\
\hline 6 & 19.7 & 19.7 & 19.7 & 19.7 \\
\hline 7 & 32.4 & 33.3 & 32.6 & 32.8 \\
\hline 8 & 43.0 & 43.1 & 43.2 & 41.9 \\
\hline 9 & 47.8 & 54.4 & 48.5 & 55.5 \\
\hline 10 & 37.4 & 37.6 & 37.5 & 37.6 \\
\hline 11 & 81.8 & 68.7 & 82.0 & 67.9 \\
\hline 12 & 124.8 & 129.0 & 121.2 & 125.5 \\
\hline 13 & 146.1 & 142.8 & 152.8 & 149.0 \\
\hline 14 & 42.0 & 42.5 & 42.3 & 43.2 \\
\hline 15 & 27.9 & 28.0 & 27.9 & 26.4 \\
\hline 16 & 26.3 & 26.6 & 26.6 & 26.0 \\
\hline 17 & 33.8 & 33.8 & 33.1 & 32.3 \\
\hline 18 & 58.7 & 58.7 & 47.0 & 46.7 \\
\hline 19 & 39.4 & 39.4 & 46.7 & 46.3 \\
\hline 20 & 39.3 & 39.5 & 31.1 & 31.0 \\
\hline 21 & 31.1 & 31.1 & 34.6 & 34.6 \\
\hline 22 & 41.3 & 41.3 & 36.9 & 36.8 \\
\hline 23 & 26.5 & 26.9 & 26.9 & 26.7 \\
\hline 24 & 21.4 & 21.2 & 21.5 & 21.5 \\
\hline 25 & 18.1 & 16.2 & 18.0 & 16.2 \\
\hline 26 & 16.2 & 17.5 & 16.2 & 17.9 \\
\hline 27 & 22.0 & 23.0 & 24.7 & 26.1 \\
\hline 28 & 28.5 & 28.7 & 28.5 & 28.7 \\
\hline 29 & 17.5 & 18.0 & 33.2 & 33.0 \\
\hline 30 & 21.3 & 21.5 & 23.6 & 23.6 \\
\hline
\end{tabular}

4.59 (H-11 of both compounds) gave response for the signals at $\delta 124.8 / 146.1$ and at $\delta 121.2 / 152.8$ (C-12, $\mathrm{C}-13)$; the irradiation at $\delta 5.45$ or at $\delta 5.38(\mathrm{H}-12)$ gave response for the signals at $\delta 58.7 / 47.0(\mathrm{C}-18)$ and at $\delta$ 42.0/42.3 (C-14). As for 1, decoupling experiments correlated the proton signals $\mathrm{H}-12, \mathrm{H}-11$ and $\mathrm{H}-9$. In conclusion, the mixture is constituted of 3-oxo-11hydroxy-urs-12-ene and 3-oxo-11-hydroxy-olan-12-ene. Literature survey for 11-hydroxy-ursane/oleanes led to two compounds, 3-oxo-11 $\alpha$-hydroxy-olean-12-ene (7) ${ }^{11}$ and 3-oxo-11 $\alpha$-hydroxy-urs-12-ene (8), ${ }^{12}$ whose ${ }^{13} \mathrm{C}$ NMR data are reported in Table 2. Comparison between $\mathbf{2}$ and 7 revealed a large difference $(+13.1 \mathrm{ppm})$ for the carbon 11 attributed to a different stereochemistry of the 11-OH (ipso effect). Differences can be also observed for C-9 (-6.6 ppm) and C-12 (-4.2 ppm), and for C-13 (+3.3 ppm). Therefore, it was concluded that compound $\mathbf{2}$ is the 11-epimer of $\mathbf{7}$, i.e. 3-oxo-11 $\beta$-hydroxy-urs-12-ene. Similar differences were found between $\mathbf{3}$ and $\mathbf{8}$, therefore the compound $\mathbf{3}$ is 3 -oxo-11 $\beta$-hydroxy-olean-12-ene. Consequently, also previous compound 1 has a $11-\beta$-hydroxy substituent. During the search in the literature a compound which claimed to be $3 \alpha, 11 \alpha$-dihydroxy-olean-12-ene, it was found. ${ }^{13}$ Nevertheless, the signal for $\mathrm{C}-11$ is reported at $\delta$ 81.8 so that its structure should be revised to $3 \alpha, 11 \beta$ dihydroxy-olean-12-ene.

Recently was reported the isolation of $3 \beta, 16 \beta, 11 \alpha$ trihydroxyurs-12-ene from Trattinnickia burserifolia. ${ }^{14}$ The signals of ${ }^{13} \mathrm{C}$ NMR were $\delta 68.2$ for $\mathrm{C}-11 \alpha$ and $\delta 66.7$ for $\mathrm{C}-16 \beta$, being these values confirmed by NOESY experiments. Such important data confirm our previous conclusions.

The treatment of animals with (1) $\left(10-100 \mathrm{mg} \mathrm{kg}^{-1}\right.$, i.p.) or (mixture 2, 3) (10 - $60 \mathrm{mg} \mathrm{kg}^{-1}$, i.p.), given $30 \mathrm{~min}$ prior formalin injection, produced marked inhibition of both phases of formalin-induced nociception (Figure 1 and 2). However, its antinociceptive effects were significantly more pronounced against the second phase of pain model. The calculated $\mathrm{ID}_{50}$ 's values for second phases were $26.9(12.5$ - 58.1) and $53.5(37.6$ - 76.1) $\mathrm{mg}$ $\mathrm{kg}^{-1}$ for compound (1) and (mixture 2,3), respectively. The maximal inhibitions observed for (1) were: $44 \pm 1 \%$ and $76 \pm 11 \%$ for the first and second phase, and (mixture 2, 3).were $54 \pm 7 \%$ and $66 \pm 12 \%$, respectively. This is the
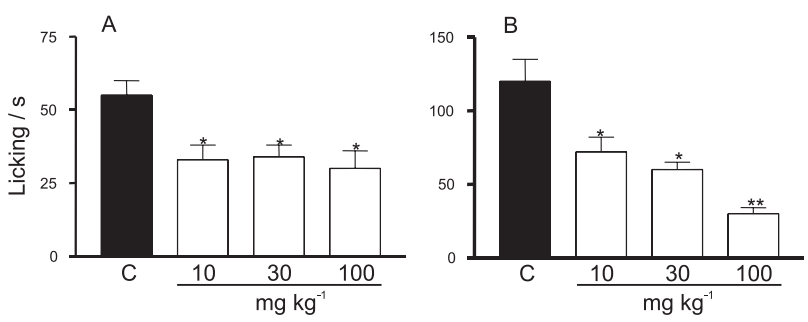

Figure 1. Effects of (1) given intraperitoneally (10-60 $\left.\mathrm{mg} \mathrm{kg}^{-1}\right)$ against the early (panel A) and the late phase (panel B) of formalininduced licking in mice. The total time (mean \pm S.E.M.) spent licking the hindpaw was measured in the first phase $(0-5 \mathrm{~min})$ and the second phase (15-30 min) after subplantar injection of formalin into the hindpaw. Each point represents the mean \pm S.E.M. for 6-10 animals. The asterisks denote the significance levels when compared with control groups. Significantly different from controls, $* \mathrm{P}<0.05$ and $* * \mathrm{P}<0.01$
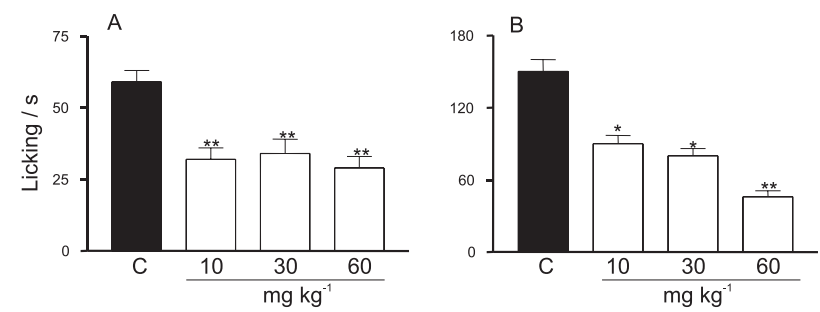

Figure 2. Effects of (mixture 2, 3) given intraperitoneally (10-100 $\mathrm{mg} \mathrm{kg}^{-1}$ ) against the early (panel A) and the late phase (panel B) of formalin-induced licking in mice. The total time (mean \pm S.E.M.) spent licking the hindpaw was measured in the first phase (0-5 min) and the second phase (15-30 $\mathrm{min})$ after subplantar injection of formalin into the hindpaw. Each point represents the mean \pm S.E.M. for 6-10 animals. The asterisks denote the significance levels when compared with control groups. Significantly different from controls, $* * \mathrm{P}<0.01$. 
first report showing the biological activity of these compounds. Furthermore, 1, 2, 3 seems to be responsible, at least in part, for the antinociception properties of the ether fraction.

\section{Experimental}

${ }^{1} \mathrm{H}$ and ${ }^{13} \mathrm{C} \mathrm{NMR}\left(\mathrm{CDCl}_{3}\right) ; 300 \mathrm{MHz}$ and $75 \mathrm{MHz}$, respectively, Variam Gemini 300. EIMS; direct inlet, 70 eV, Shimadzu. Elemental analisys Elemental CHN PerkinElmer 2400.

\section{Plant material}

Protium kleinii Cuatrecas (Burseraceae) was collected at Morro do Baú, Ilhota (Santa Catarina, Brazil) in January 1999 and identified by Prof. Ademir Reis (Depto de Botanica, Universidade Federal de Santa Catarina). A voucher (VC Filho 22) was deposited in the Barbosa Rodrigues Herbarium, Itajaí.

\section{Extraction and fractionation}

The resinous bark (50 g) was powered and extracted with diethyl eter at room temperature for two weeks. After evaporation of the solvent, part (14.4 g) of the brown residue (33.4 g) was chromatographed on silica gel column with a gradient of EtOAc in hexane. Fractions 11-15 (eluted with hexane:EtOAc, 49/1, v/v) afforded after repeated crystallizations a 2:3 inseparable mixture (45 mg) of 3oxo- $11 \beta$-hydroxy-urs-12-ene (2) and 3-oxo-11 $\beta$-hydroxyolean-12-ene (3). Fractions 21-32 (hexane: EtOAc, 24/1) $(5 \mathrm{~g})$ was constituted by an inseparable mixture of $\alpha(5)$ and $\beta$-amyrin (6). Fractions 59-73 (hexane: EtOAc, 4/1) gave 3-oxo-11 $\beta$, 16 $\beta$-dihydroxy-urs-12-ene, (1), (35 mg). Fractions 81-83 (hexane:ethyl acetate, 1/1) was pure $3 \beta \mathrm{b}, 16 \beta$-dihydroxy-urs-12-ene (brein), (4) (2.5 g).

The identification of the known compounds was performed by comparison of NMR data with those reported in the literature: mixture of $\alpha$ - and $\beta$-amyrin, ${ }^{4}$ and $3 \beta, 16 \beta$, dihydroxy-urs-12-ene (brein). ${ }^{14}$

3-oxo-11 $\beta, 16 \beta$-dihydroxy-urs-12-ene (1). White solid, Anal. Calc. for $\mathrm{C}_{30} \mathrm{H}_{48} \mathrm{O}_{3}: \mathrm{C}, 78.90 ; \mathrm{H}, 10.59$. Found: C, 78.75; H, 10.65\%. NMR data in Table 1. EIMS (probe) 70 $\mathrm{eV}, \mathrm{m} / \mathrm{z}$ (rel. int): $456\left[\mathrm{M}^{+}\right]$(4), 289 (71), 248 (100), 207 (65), 175 (49), 135 (85).

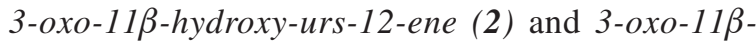
hydroxy-olean-12-ene (3). Isolated as an 2:3 mixture. Anal. Calc. for $\mathrm{C}_{30} \mathrm{H}_{48} \mathrm{O}_{2}: \mathrm{C}, 81.76 ; \mathrm{H}, 10.98$. Found: C, 81.65; $\mathrm{H}$, 11.05\%. ${ }^{1} \mathrm{H}$ NMR (2): $\delta 5.38$ (d, J 3.0 Hz, H-12), 4.56 (dd, $J 9.4$ and $3.0 \mathrm{~Hz}, \mathrm{H}-11$ ), 2.00 (d, J 9.4 Hz, H-9). ${ }^{1} \mathrm{H}$ NMR
(3): $\delta 5.45$ (d, $J 2.8 \mathrm{~Hz}, \mathrm{H}-12), 4.59$ (dd, $J 9.4$ and $2.8 \mathrm{~Hz}$, H-11), 2.00 (d, J 9.4 Hz, H-9). ${ }^{13}$ C NMR (2 and 3) in Table 2. EIMS (probe) $70 \mathrm{eV}, \mathrm{m} / \mathrm{z}$ (rel. int.): $440\left[\mathrm{M}^{+}\right]$(5), 273 (84), 233 (17), 232 (48), 206 (7) 149 (23) 148 (23), 135 (100).

\section{Pharmacological analysis}

Animals. Male Swiss mice (25-35 g), housed at $22 \pm$ $2^{\circ} \mathrm{C}$ temperature under a $12 \mathrm{~h}$ light/12 h dark cycle and with access to food and water ad libitum, were used. Experiments were performed during the light phase of the cycle. The animals were allowed to adapt to the laboratory for at least $2 \mathrm{~h}$ before testing and were used only once. Experiments reported in this study were carried out in accordance with current ethical guidelines for the investigation of experimental pain in conscious animals. ${ }^{16}$

Formalin test. The procedure used was essentially similar to that described previously. ${ }^{17,18} 20 \mathrm{~mL}$ of $2.5 \%$ formalin solution $(0.92 \%$ of formaldehyde), made up in PBS ( $\mathrm{NaCl} 137 \mathrm{~m} 7 \mathrm{mmol} \mathrm{L}^{-1}, \mathrm{KCl} 2.7 \mathrm{mmol} \mathrm{L}{ }^{-1}$. and phosphate buffer, $10 \mathrm{~m} 7 \mathrm{mmol} \mathrm{L}^{-1}$ ), were injected intraplantarly under the surface of the right hindpaw. Animals were treated with triterpenes (1) (10-30 mg kg-1, i.p.) and (mixture 2,3$)\left(10-60 \mathrm{mg} \mathrm{kg}^{-1}\right.$, i.p.) or vehicle (10

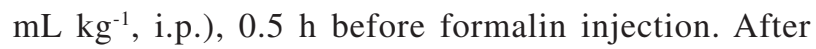
intraplantar injection of formalin, the animals were immediately placed in a glass cylinder $20 \mathrm{~cm}$ in diameter and the time spent licking the injected paw was measured with a chronometer, during 30 mins. The initial nociceptive scores normally peacked after $5 \mathrm{~min}$ (first phase, representing the neurogenic pain), and after 15-30 min after formalin injection (second phase, representing the inflammatory pain), this time being considered as indicative of nociception.

Statistical analysis. The results are presented as means \pm S.E.M., except the $\mathrm{ID}_{50}$ values (it. the dose of (1) reducing the pain responses by $50 \%$ relative to the control value) which are reported as geometric means accompanied by their respective $95 \%$ confidence limits. Data were analyzed by analysis of variance (ANOVA) or $t$-test and complemented by Dunnett's or Newman Keul's post-hoc test. $\mathrm{P}$ values less than $0.05(\mathrm{P}<0.05)$ were considered as indicative of significance. The $\mathrm{ID}_{50}$ values were determined by linear regression from individual experiments using "GraphPad Software", and are reported as geometric means accompanied by their respective $95 \%$ confidence limits.

Drugs. The following substances were used: formalin (Merck, AG, Darmstadt, Germany), was dissolved in $0.9 \%$ $\mathrm{m} / \mathrm{v}$ of $\mathrm{NaCl}$ solution just before injection while capsaicin and ether fraction which were dissolved in absolute ethanol 
and tween 80 plus $0.9 \% \mathrm{~m} / \mathrm{v}$ of $\mathrm{NaCl}$ solution, respectively. The final concentration of tween 80 or ethanol did not exceed $5 \%$ and did not cause any effect it.

\section{References}

1. Pernet, R.; J. Nat. Prod. 1972, 35, 280.

2. Duwiejua, M.; Zeitlin, I.J.; Waterman, P.G.; Chapman , J.; Mhango, G.J.; Provan, G.J.; Planta Med. 1993, 59, 12.

3. Siani, A.C.; Ramos, M.F.S.; Lima, O.M.; Santos, R.R.; Ferreira, E.F.; Soares, R.O.A.; Rosas, E.C.; Susunaga, G.S.; Guimarães, A.C.; Zoghbi, M.G.B.; Henriques, M.G.M.O.; J. Ethnopharmacol. 1999, 66, 57.

4. Maia, R.M.; Barbosa, P.R.; Cruz, F.G.; Roque, N.F.; Fascio, M.; Quim. Nova 2000, 23, 623.

5. Susunaga, G.S.; Siani, A.C.; Pizzolatti, M.G.; Yunes, R.A.; Delle Monache, F.; Fitoterapia 2001, 72, 709.

6. Reitz, R.; Flora Ilustrada Catarinense., I Parte, R. Reitz, ed.: Itajaí, 1981.

7. Otuki, H.F.; Lima, F.V.; Malheiros, A.; Cechinel Filho, V.;
Delle Monache, F.; Yunes, R.A.; Calixto, J.B.; Life Sci. 2001, 69, 2225.

8. Johns,S.R.; Lamberton, J.A.; Morton, T.C.; Suares, H.; Willing, R.I.; Austr. J. Chem. 1983, 36, 2537.

9. Olea, R. S.; Roque, N.F.; Quim. Nova 1990, 13, 278.

10. Mahato, S.B.; Kundu, A.P.; Phytochemistry 1994, 37, 1517.

11. Luis, J.G.; Andres, L.S.; Nat. Prod. Lett. 1999, 13, 187.

12. Xiao, Y.; Guo-Liang, W.; Fu-Jun, G.; Acta Bot. Sin. 1994, 36, 153. (C A 121: 226446f, 1994).

13. Ikuta, A.; Morikawa, A.; J. Nat. Prod. 1992, 55, 1230.

14. Lima, M. P.; Braga, P. A. C.; Macedo, M. L.; Silva, M. F. G. F.; Ferreira, A. G.; Fernandes, J. B.; Vieira, P. C.; J. Braz. Chem. Soc. 2004, 15, 385.

15. Tamai, M.; Watanabe, N.; Sonay, A.M.; Kondoh, H.; Omnia, S.; Zhang, P.L.; Chang, W.M.; Planta Med. 1989, 55, 44.

16. Zimmermann, M.; Pain 1983, 16, 109.

17. Correa C.R, Calixto J.B.; Br. J. Pharmacol. 1993, 110, 193.

18. Vaz, Z.R.; Cechinel Filho, V.; Yunes R.A.; Calixto J.B.; J. Pharmacol. Exp. Ther. 1996, 278, 304.

Received: July 15, 2003 Published on the web: March 15, 2005 